\title{
Atypical presentation of a Meckel's diverticulum
}

\author{
Maryam Alfa-Wali, ${ }^{1}$ Stacy Wardle, ${ }^{1}$ Shiyam Nizar, ${ }^{2}$ Ian T Bloom ${ }^{2}$
}

${ }^{1}$ Department of Surgery, Epsom \& St Helier Hospital, London, UK

2Department of Surgery, Kingston Hospital NHS Trust Surrey, UK

\section{Correspondence to}

Maryam Alfa-Wali,

m.alfa-wali@imperial.ac.uk

Accepted 28 January 2016

\section{DESCRIPTION}

A 36-year-old man presented with a 3-day history of right loin to groin colicky pain. He reported anorexia but had no urinary symptoms, no nausea and no vomiting. He had no medical history and no drug history of note. On examination, he was afebrile with normal vital signs. His abdomen was soft and non-tender, and he had normal external genitalia. His urine dipstick showed $3+$ of blood. His white cell count was 3.6 (range $3.5-11) \times 10^{9} / \mathrm{L}$, he had a C reactive protein of $49 \mathrm{mg} / \mathrm{L}$ (normal $<7 \mathrm{mg} / \mathrm{L}$ ), and urea and creatinine of 7.2 (range 2.5-7.1) $\mathrm{mmol} / \mathrm{L}$ and 225 (44-120) $\mu \mathrm{mol} / \mathrm{L}$, respectively. The working diagnosis was renal calculi.

A CT scan of the abdomen and pelvis (figure 1) was performed, which revealed a $5 \mathrm{~cm}$ gas and fluid-containing lesion with enteroliths in a Meckel's diverticulum, directly anterior to a loop of terminal ileum lying inferior to the caecal pole.

A diagnostic laparoscopy established the diagnosis of a large Meckel's diverticulum (figure 2), which was resected using an endoscopic stapling device, as previously reported. ${ }^{1}{ }^{2}$ The histological examination confirmed three layers of small intestine consistent with a Meckel's diverticulum-with no evidence of dysplasia or malignancy-containing multiple enteroliths. The patient made a successful postoperative recovery with his renal function returning to normal.

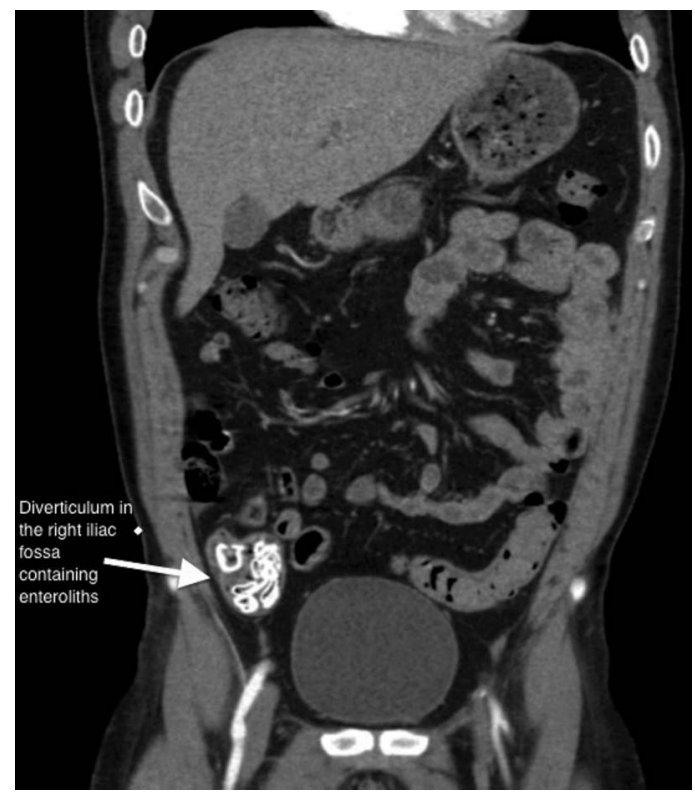

Figure 1 Coronal CT scan of the abdomen and pelvis indicating a Meckel's diverticulum with enteroliths.

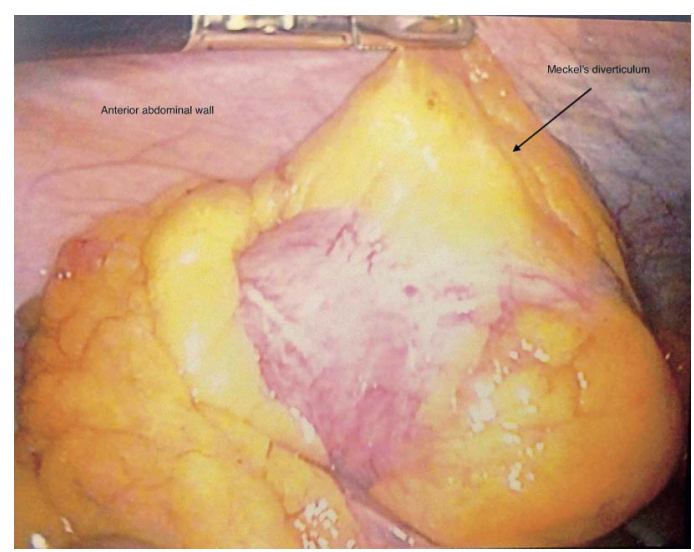

Figure 2 Intraoperative laparoscopic image of the diverticulum.

Meckel's diverticulum is a congenital abnormality of the small bowel occurring in approximately $2 \%$ of the population, and commonly presents with gastrointestinal bleeding, bowel obstruction, perforation and intussusception. ${ }^{3}$ In our case, however, the presentation was loin to groin pain.

\section{Learning points}

- Use of appropriate investigations to confirm the diagnosis and for surgical planning is very important.

- Safe management of a large Meckel's diverticulum is performed using laparoscopic resection.

Twitter Follow Maryam Alfa-Wali at @Ecosurg

Contributors MA-W and SW performed the literature search. All the authors edited and reviewed the manuscript.

Competing interests None declared.

Patient consent Obtained.

Provenance and peer review Not commissioned; externally peer reviewed.

\section{REFERENCES}

1 Chan KW, Lee KH, Mou JW, et al. Laparoscopic management of complicated Meckel's diverticulum in children: a 10-year review. Surg Endosc 2008;22:1509-12.

2 Dumper J, Mackenzie S, Mitchell P, et al. Complications of Meckel's diverticula in adults. Can J Surg 2006;49:353-7.

3 Hosn MA, Lakis M, Faraj W, et al. Laparoscopic approach to symptomatic Meckel diverticulum in adults. JSLS 2014;18: e2014.00349. 
Copyright 2016 BMJ Publishing Group. All rights reserved. For permission to reuse any of this content visit http://group.bmj.com/group/rights-licensing/permissions.

BMJ Case Report Fellows may re-use this article for personal use and teaching without any further permission.

Become a Fellow of BMJ Case Reports today and you can:

- Submit as many cases as you like

- Enjoy fast sympathetic peer review and rapid publication of accepted articles

- Access all the published articles

- Re-use any of the published material for personal use and teaching without further permission

For information on Institutional Fellowships contact consortiasales@bmjgroup.com

Visit casereports.bmj.com for more articles like this and to become a Fellow 